\title{
Design and implementation of a voluntary collective earthquake insurance policy to cover low-income homeowners in a developing country
}

\author{
Mabel C. Marulanda ${ }^{1}$, Omar D. Cardona ${ }^{2}$, Miguel G. Mora ${ }^{3}$ and Alex H. Barbat ${ }^{4}$
}

\begin{abstract}
Understanding and evaluating disaster risk due to natural hazard events such as earthquakes creates powerful incentives for countries to develop planning options and tools to reduce potential damages. The use of models for earthquake risk evaluation allows obtaining outputs such as the loss exceedance curve, the expected annual loss and the probable maximum loss, which are probabilistic metrics useful for risk analyses, for designing strategies for risk reduction and mitigation, for emergency response strategies and for risk financing. This article presents, based on probabilistic risk models, the design and implementation of a risk transfer instrument to cover the private buildings of the city of Manizales, Colombia. This voluntary collective instrument provides financial protection to both, the estate-tax payers and the low-income homeowners through a cross subsidy strategy; besides, it promotes not only the insurance culture but also the solidarity of the community. The city administration and the insurance industry are promoting this program using the mechanism of the property-tax payment. This collective insurance helps the government to access key resources for low-income householders recovery and improve disaster risk management at local level.
\end{abstract}

Keywords: Seismic risk insurance instruments, earthquake risk model, probable maximum loss, expected annual loss, risk premium, cross-subsidy strategy

\section{INTRODUCTION}

Social, environmental and economic sustainability depend not only on the identification of risk conditions but also on planning measures and implementing development activities that allow reducing possible future losses of society. Thus, the level of risk is directly related to the development and the capacity to intervene the existing risk. Sustainable development means actions at a short, medium and long term that focus on a prevention culture construction. Nevertheless, this is not an easy task because the costs of prevention

\footnotetext{
${ }^{1}$ Researcher Centre Internacional de Mètodes Numèrics en Enginyeria (CIMNE). Universidad Politécnica de Cataluña. Campus Norte. C/Gran Capitán sn Mod. C1, 08034, Barcelona, Spain. 
have to be paid in the present and its benefits, which are not tangible, lie in a distant future. The benefits are the disaster that did not happen, as was pointed out by Kofi Annan, UN General Secretary, in 1999. In addition, individuals faced with the possibility of a catastrophic loss tend to ignore the event until it occurs. Usually, prior to a catastrophe, individuals underestimate the chances of such a disaster occurring (Marulanda et al., 2008).

Risk management is a fundamental development strategy that considers four principal policies: risk identification (risk assessment, risk communication and awareness), risk reduction (prevention and mitigation), disaster management (emergency response, rehabilitation and recovery) and risk financing (retention and transfer) (Birkmann et al., 2013). One of the key strategic activities of disaster risk management is the risk assessment, which requires the use of reliable methodologies that allow an adequate probabilistic calculation of losses in the exposed elements due to the occurrence of extreme events. The results obtained by using models of catastrophe risk assessment make feasible determining the potential deficit in the case an extreme event occurs. Catastrophe risk models -based on probabilistic metrics such as the Probable Maximum Loss and the Average Annual Loss- are used to estimate, sometimes building by building, the losses of different exposed elements portfolios. Usually, these kind of evaluations have been performed by private financial markets; nevertheless, at present, it is understood that estimations and quantification of potential losses in a given exposure time are of interest

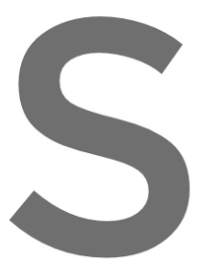
not only for private insure budget for both the emergency response and
fiscal exposure and a non-explicit dontingent
levels (Pollner, 2001; Andersen, 2002). In ad
information and permits setting out ex ant (Marulanda et al., 2008; 2010; Cardona
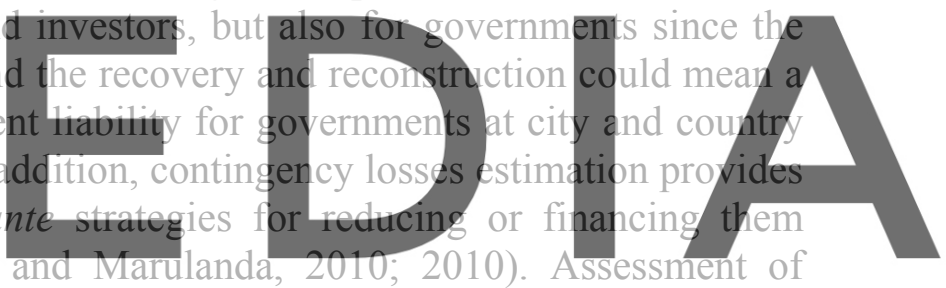

potential losses allows both the consideration of budget allocation for structural retrofitting

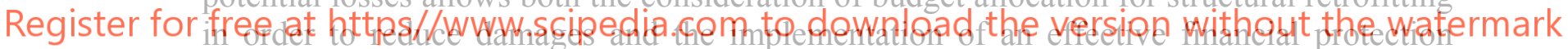

strategy to provide loss coverage of public infrastructure and private buildings, to protect thus government resources and to safeguard socioeconomic development. In summary, to achieve a greater awareness, security culture and economic prosperity, the financial protection must be a permanent and long term policy (Freeman et al., 2003).

Some government catastrophe schemes have been proposed around the world, some of them being implemented. A publication made by the Consorcio de Compensación de Seguros in Spain (Consorseguros, 2008) provides a detailed review of those schemes existent worldwide. One of the most known earthquake insurance scheme is the Turkish Catastrophe Insurance Pool that was launched in 2000 and it became the first catastrophe insurance program in a middle-income country. This insurance focuses on the registered urban dwellings (middle-income homeowners) while the rural settlements (low-income homeowners), which are excluded from this program, are financially supported by the government (Gurenko et al., 2006). Other existent initiatives are the disaster microinsurance meant to providing low-income households and businesses with easily accessible and affordable insurance scheme. Mechler et al. (2006) present a background of the disaster microinsurance and an overview of this kind of scheme and of its characteristics. 
It is important to remember that insurance or, in general, risk financing strategies, are not mitigation measures strictly speaking, because they do not reduce damage, and its objective is to cover economic losses once the risk is materialized (Cardona et al., 2008d). However, "world experience shows that disaster insurance has two big advantages: stimulate prevention oriented by insurers and guarantee financing and efficiency in post disaster reconstruction activities" (Vargas, 2002).

The persistence of negative impacts in the city of Manizales, Colombia, has become a concern due to the fiscal and the social difficulties they represent for the local government. Given the joint work between the local government, the academia and the private sector of Manizales, since several years ago, a notable progress in risk management has been achieved. The development of detailed seismic information, including the microzonation of the city (ITEC, 2004), as well as the gathering of accurate information of the assets of the city, have been the base to design an innovative insurance scheme and to promote the insurance culture, in terms of the earthquake insurance promotion for low-income homeowners. The computer platform used for these evaluations was the RN-Col v.2.1, a probabilistic seismic risk assessment model (today the R System) developed by Evaluación de Riesgos Naturales - (ERN, 1999).

The social benefit of the risk transfer mechanism of Manizales is evident when properties of the low-income homeowners are covered without cost for them. This is the reason why

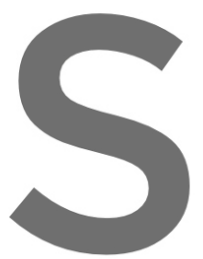
the design and the in public and private assets of the of the local governm The premium or insurance of the property
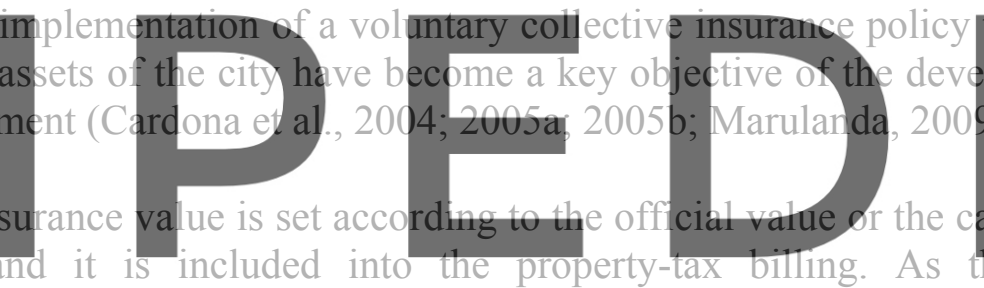

subscription is voluntary, when the payment of the property tax is made (each two months

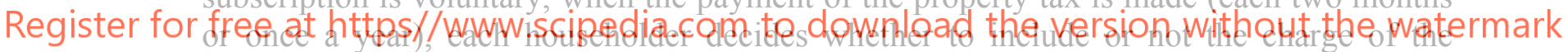

insurance premium of his property. The city administration uses its information systems to compute and to ease the collection of the insurance payment of the properties of the city, the insurance company has the direct contractual relationship with the insured and, therefore, it solves problems and processes the claims derived from the policy (Marulanda, 2009).

In this article we describe the probabilistic seismic risk model and the steps followed to obtain the probable losses and the average annual loss of each private building of the city of Manizales. We also show how the results are used for designing the collective risk transfer instrument that covers the losses of poor homeowners by cross-subsidies.

\section{DESCRIPTION OF THE PROBABILISTIC SEISMIC RISK MODEL}

Seismic risk models are used to calculate the probable losses that a catastrophic event could generate in a region. Limited information is available for low frequency, catastrophic events, fact which leads to large uncertainties related to the seismic events that require a probabilistic treatment (Egozcue et al., 1991). The probabilistic risk assessment model simulates scientifically credible events that might happen in the future. In general, the catastrophe models maximize the available information necessary to assess the potential 
losses that can produce extreme events and it is important to have in mind the effects of the uncertainties upon the outputs that have to be considered in decision-making.

The structure of a risk model is composed of a sequence of processes or modules allowing to perform hazard assessment, vulnerability assignation, risk evaluation (assessment of potential losses) (Barbat et al., 2006; Barbat et al., 2010) as well as of a number of applications making use of the risk results (Woo, 1999, 2011; Grossi and Kunreuther, 2005; Cardona et al., 2008a). The basic structure of such a model is shown in Figure 1. The grey part corresponds to RN-Col v.2.1 computer system modules.

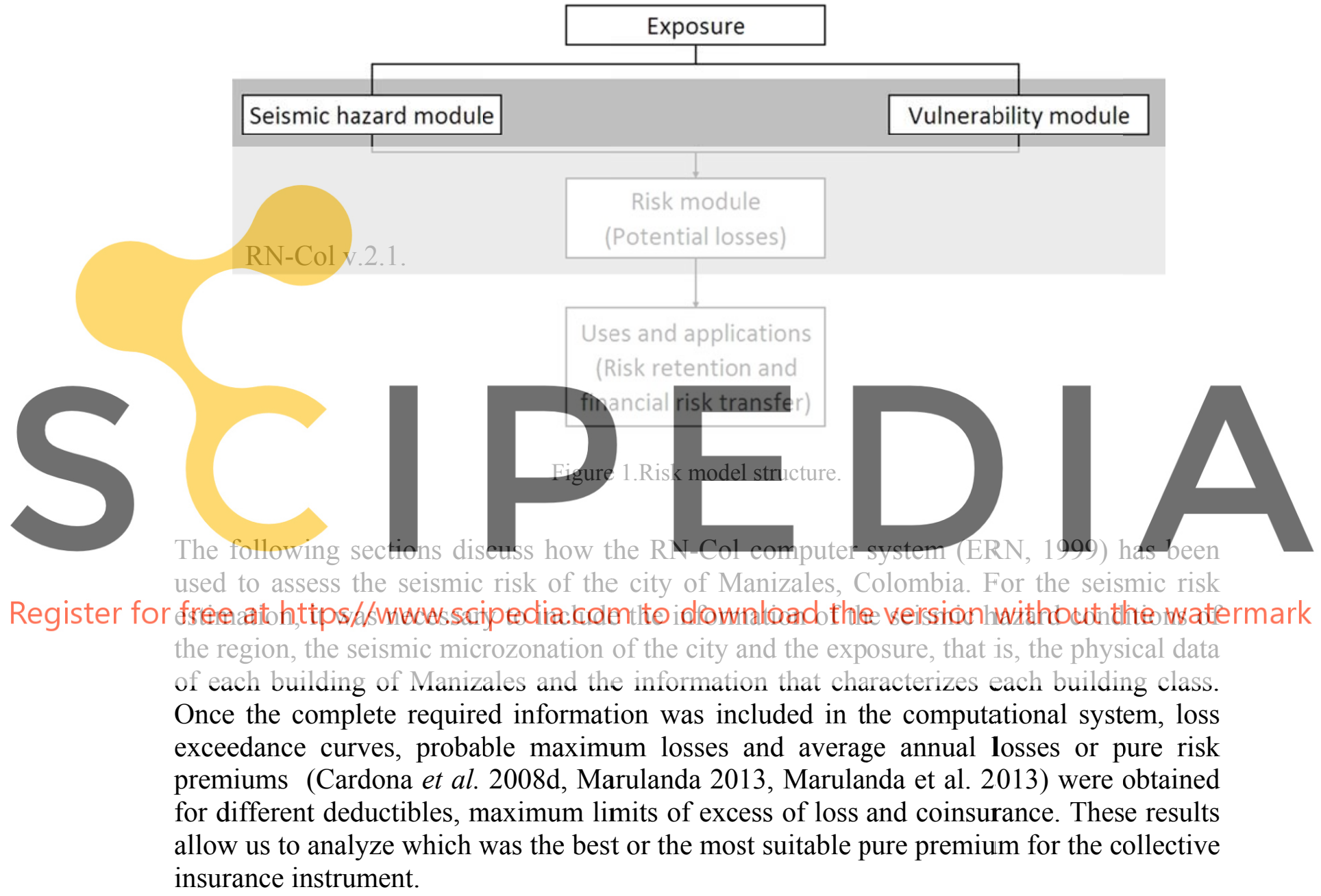

\section{EXPOSURE}

The exposure or the exposed assets include an inventory of buildings to estimate the probable losses. The exposure considered in the evaluation performed in this article consisted of all the 85,816 private buildings of Manizales, Colombia (cadastral data of 2009). Each property was characterized by the essential information such as location, value of replacement, construction class and year of construction. When updated property values were available, the database was updated. The cadastral information was mainly obtained 
from the Municipal Directorate of Disaster Risk Management and additional information was taken from other municipality databases ${ }^{5}$.

According to the socio-economic classification used in Colombia ${ }^{6}$, three portfolios or groups of buildings were defined: (a) low-income householders portfolio (corresponding to socio-economic layers 1 and 2 of Colombia), (b) property-tax payer's portfolio (socioeconomic layers 3 to 6 of Colombia) and (c) complete portfolio (socio-economic layers 1 to 6). Table 1 shows the three portfolios with their number of records and the insured value which, in this case, is the cadastral value.

Table 1.General data of the portfolios of private buildings of Manizales.

The insured value is given in Col\$ (US\$ $1=\mathrm{Col} \$ 2,000)$

\begin{tabular}{clccc}
\hline Portfolio & Description & $\begin{array}{c}\text { Number of } \\
\text { records }\end{array}$ & \% registers & $\begin{array}{c}\text { Insured value } \\
\text { (Million } \\
\text { COLS) }\end{array}$ \\
\hline 1 & Exempt of property tax & 15,342 & $18 \%$ & $\begin{array}{c}\text { \% insured } \\
\text { value }\end{array}$ \\
2 & Non-exempt of property tax & 70,474 & $82 \%$ & $3 \%$ \\
3 & Total private buildings & 85,816 & $100 \%$ & $97 \%, 036,460$ \\
\hline
\end{tabular}

Figure 2 shows the physical value of the private buildings of Manizales. The yellow colour corresponds to the buildings with a value below Col\$8,950,000 (socio-economic layers 1 and 2), and the colours from orange to red correspond to buildings with values greater than Co1 $\$ 8,950,000$, that is, to the layers 3 to 6 of the taxpayers.
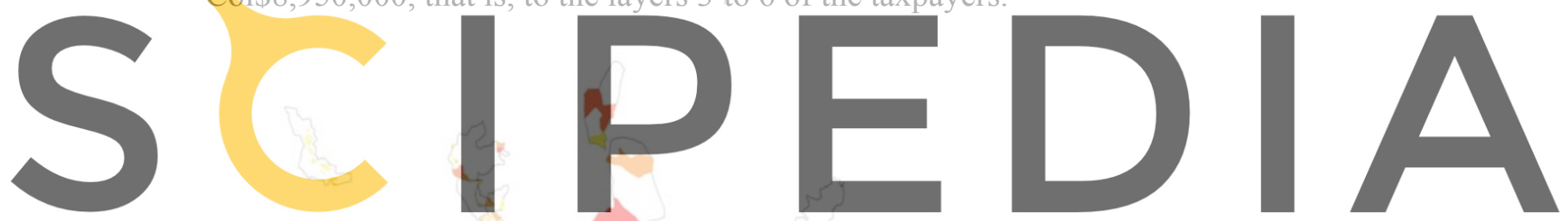

Register for free at https//www.scipedia.com to download the versionimaithoutishe watermark

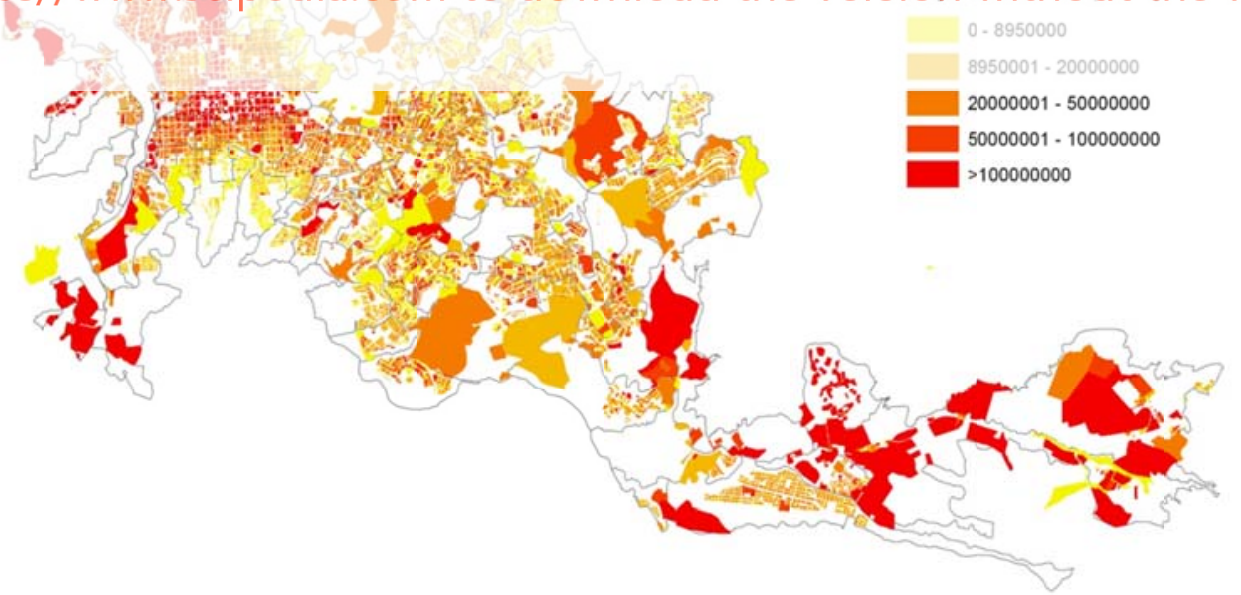

Figure 2. Exposed value of the private buildings of the city of Manizales, Colombia

\footnotetext{
${ }^{5}$ More detailed parameters were included by field visits, aerial photographs and maps. Additionally, in cases where information did not exist or it was not possible to infer it from new sources, an optimization algorithm was used to define it (Marulanda, 2009).

${ }^{6}$ The socio-economic classification in Colombia is made by "layers" according to different socio-economical characteristics of the population: Layers 1 and 2 include people with very low economic capacity, while layers from 3 to 6 include property tax payers. This classification is used to differentiate charge public services, allowing the assignment of subsidies and the collection of contribution (Statistic National Administrative Department of Colombia, DANE, in Spanish)
} 


\section{SEISMIC HAZARD MODULE}

The seismic hazard module defines the probability of exceeding certain levels of the ground motion intensity at particular locations. The analysis comprehends the sources, the frequency of occurrence and a measure of the intensity of the earthquakes at specific sites. The definition of these parameters of the seismic events is based on the review of the historical information available for the studied area and on scientific studies. The module generates a set of thousands of stochastic events once the probability distributions of each parameter are defined, which characterize the activity rates of each faulting system. More detailed information about the description of the seismic hazard module can be found in Cardona et al. (2008d), Cardona et al. (2010b), Marulanda (2013), Marulanda et al. (2013).

\section{In the case of Manizales, the module of seismic hazard includes:}

The seismic parameters, such as the lower and upper bound magnitudes, the occurrence rate of the earthquakes and other parameters defining the seismic hazard of Colombia (AIS-300, 1996, 2010; Salgado et al. 2010, 2013).

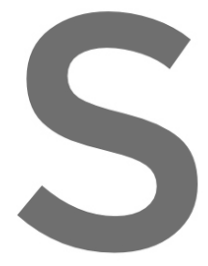

The attenuation of the seismic event from its epicenter to the site under consideration, has to be inouded. The attenuation laws capture how intensity changes when an earthquake propagates over an area. Thereby, the model consider the propagation of the seisutic waves by means of probabilistic spectral attenuation laws. The definition of the attenuation laws for different sources ("active" for ch continental so

based on regional recent strong motion records of Colombia, was made by Gallego,

Register for free af 200 ttips//www.scipedia.com to download the version without the watermark The local soil eifects can generate important effects on the amplitude and on the frequency of the waves. Manizales counts with detailed studies on the dynamic properties of soils and on the topographic effects (CEDERI, 2002), according to which the city is subdivided in microzones.

The information of the seismic hazard is used as a step to obtain results for the probable losses. The figure 3 shows a screenshot of the $\operatorname{SisMan}^{7}$ V1.1.0 system containing results of spectral acceleration for a specific return period and using the seismic microzonation of the city (ITEC, 2004). This program allows the visualization of the seismic hazard used by the RN-Col.

The system comprehends the entire geographical information of the city, including general cartography, rivers, roads, places of interest, location of essential and special buildings, geology and geotechnical information. This tool allows displaying the seismic hazard in any area of Manizales, considering the local site effects. Exceedance rates for multiple spectral ordinates of acceleration, velocity and displacement are

\footnotetext{
${ }^{7}$ Sistema de Información Sísmica de Manizales, SisMan. Program that allows the visualization of the seismic hazard used by the RN-Col.
} 
obtained to provide the design spectra, information which is also useful for the seismic design of buildings.

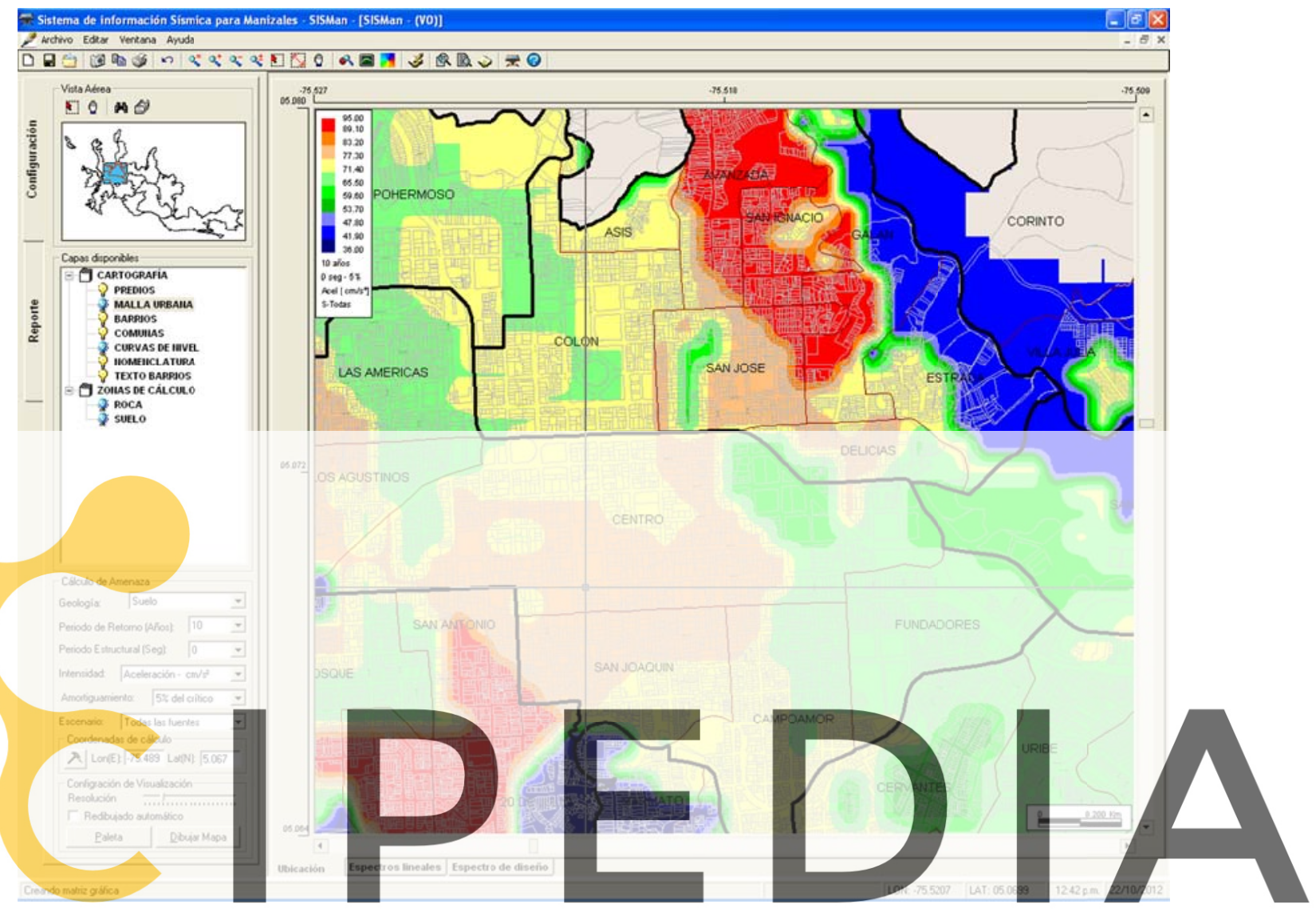

Figure 3. Screenshot obtained with the interactive software tool SisMan for the seismic microzonation of

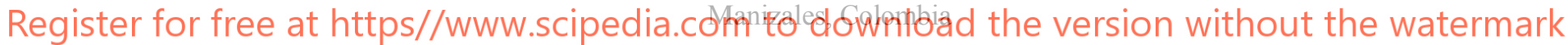

\section{VULNERABILITY MODULE}

Vulnerability functions provide all the necessary information to calculate the probability of reaching or exceeding a loss value, given a seismic demand. They quantify the level of damage expected in each building class for different levels of the intensity of the seismic events. In order to define these curves, the inventory of buildings -exposure- is classified into different building types with different characteristics (in function of the type of materials and structure, building use, number of levels, year of construction). Damage is estimated in terms of the Mean Damage Ratio, MDR, which is defined as the ratio of the expected repair cost to the economic value of the structure. A vulnerability curve is defined relating the MDR to the earthquake intensity, which can be expressed, at each location, in terms of the maximum acceleration (useful for 1-2 story buildings), spectral acceleration, velocity or interstory drift (useful for multi-story buildings) (Miranda, 1999). The range of damage ratio can go from $0 \%$ (no damage) to $100 \%$ (total loss). Due to the fact that the seismic intensity and the level of expected damage have high uncertainties, the damage ratio is also a random value. Detailed information on this issue is given in Cardona et al. (2008d), Cardona et al. (2010b), Marulanda, 2013 and Marulanda et al., 2013 
The urban characteristics and the urban evolution of Manizales increase continuously its susceptibility to seismic hazards. The city has grown in an abrupt topography area with special geological particularities, and with a lack of urban planning that has led to build in dangerous areas. Although at the beginning of the XIXth century, the most common class of buildings had a bahareque ${ }^{8}$ structure, when two disastrous fires occurred in the city in 1923 and 1925, the population started to build with other kinds of materials, safer to fires. Thus, the culture of the wood or bahareque technology was abandoned to adopt concrete and masonry as building materials. These more rigid and fragile structures, together with the increase of population and the fast urban growing, entailed a more vulnerable city to seismic actions. Nevertheless, after the earthquake of 1979 that produced important losses in the city, the first earthquake resistant building code was made in 1981 at city level, before Colombia adopted one at national level. Colombia counts with seismic building codes since 1984 (Law 400 of 1984); these codes have been continuously updated allowing a better quality of construction and this fact is reflected in the decrease of the seismic vulnerability of the assets.

\section{A total of 20 building classes are included in the RN-Col system as it is detailed inTable 2.} Figure 4 and Figure 5 show vulnerability curves in terms of peak ground acceleration and inter-story drift, respectively, for several construction classes (Cardona et al., 2008a; 2008b; 2008c; 2008d).

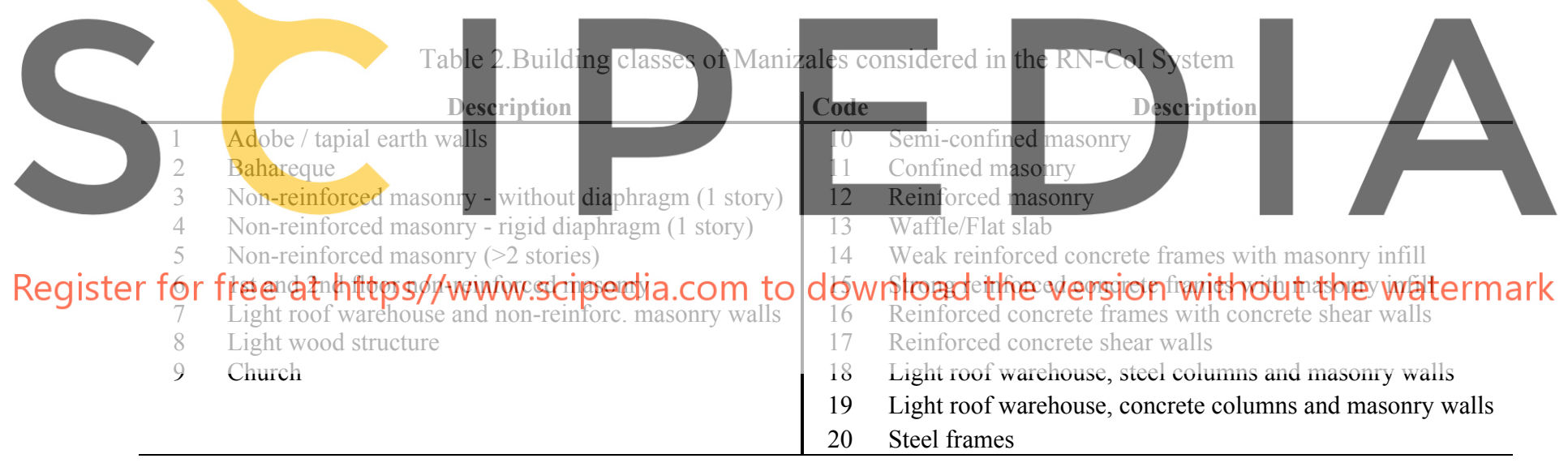

\footnotetext{
${ }^{8}$ The bahareque is a mixed timber, bamboo and mud wall construction technique. It is frequently used in some Latin-American countries.
} 


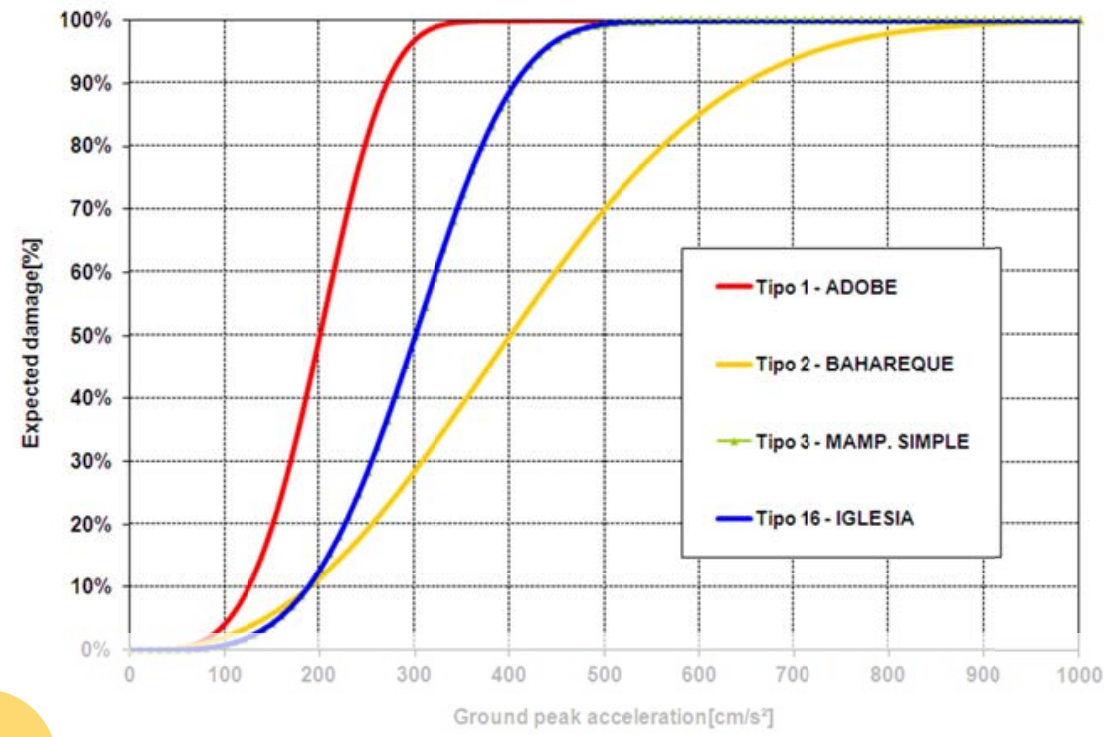

Figure 4.Vulnerability functions based on peak ground acceleration
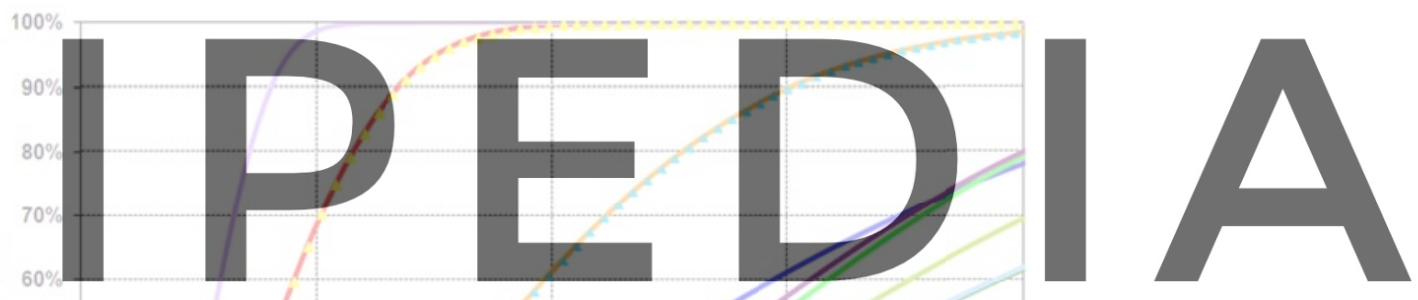

Register for free at http.s//www.scipedia.com to download the version without the watermark

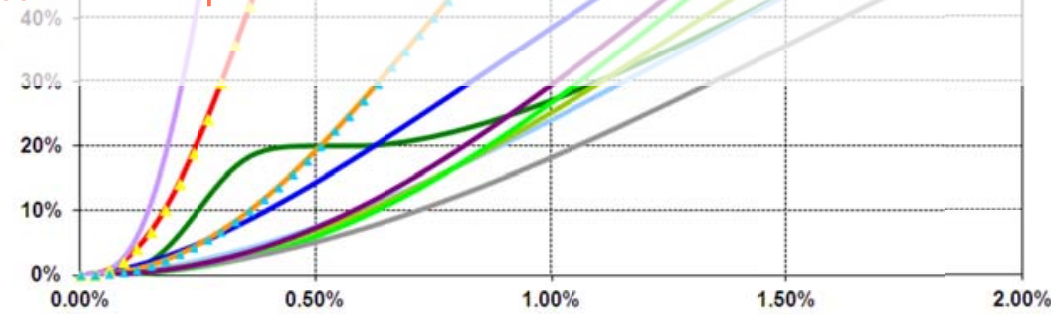

$$
\begin{array}{|lll|}
\multicolumn{3}{c}{\text { Maximum interstory drift [\%] }} \\
\hline \text {-Tipo 4 - M. CONF. } & \text { Tipo 5 - M. REF. } & \text {-Tipo 6 - PCR + MM } \\
\text {-Tipo 7 - PCR } & \text {-Tipo 8 - PCR+MCR } & \text {-Tipo 9 - RETCEL } \\
\text {-Tipo 10 - MCR } & \text {-Tipo 11 - PREFABRICADO } & \text {-Tipo 12 - P. ACERO } \\
\text {-Tipo 13,14,15 - BODEGAS } & \text { A Tipo 17 - ESTADIOS } & \text {-Tipo 18 - M. SEMI. CONF. } \\
\hline
\end{array}
$$

Figure 5.Vulnerability functions based on maximum inter-story drift

\section{RISK MODULE}

The risk module evaluates the potential effects or consequences of the natural hazardous events by means of the convolution of the hazard with the vulnerability of the exposed elements. It expresses risk in terms of physical damage, absolute or relative economic loss 
and/or affected population. Thus, this risk module calculates losses by transforming the damage ratio obtained in the vulnerability module into economic loss by multiplying it by the value at risk. The same procedure is followed for each asset class at each location. Losses are then aggregated according to the procedure proposed by Ordaz et al. (1998) and by Ordaz (2000). The loss module estimates the net losses. The main metrics used in the probabilistic risk assessment are the following:

Loss Exceedance Curve, LEC (Grossi and Kunreuther, 2005) or the Exceedance Probability Curve, EP Curve which represents the annual frequency of exceedance of a specific loss is the most important catastrophe risk metric used by risk managers, since it estimates the amount of funds required to meet risk management objectives. The $L E C$ can be calculated for the largest event in one year (Occurrence Exceedance Probability Curve, OEP curve) or for all the events (cumulative) in one year (Aggregate Exceedance Probability Curve, AEP Curve). Once obtained, the Loss Exceedance Curve allows calculating other appropriate metrics for the financial analysis of the losses such as the Average Annual Loss or the Probable Maximum Loss.

Average Annual Loss, AAL, is the expected loss per year. It is also denominated Pure Risk Premium. Computationally, the AAL is the sum of the product of the expected losses due to a specific event and the annual occurrence probability of that event, for all stochastic events considered in the loss model. The average annual loss considers the losses in each

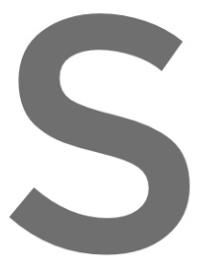
building for all the hazard events is stationary after an event.

Probable Maximum Loss, PML (equivalent to
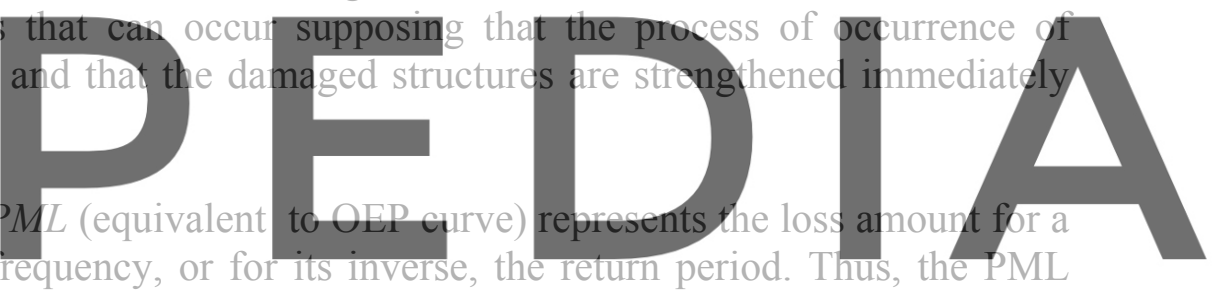
expresses the economic value of loss with regard to the return period. The PML is an

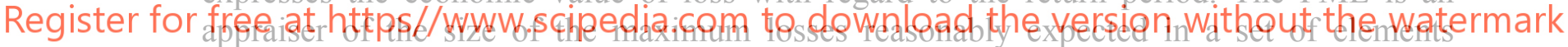

exposed to a hazard event. Typically, PML is a fundamental metric to determine the size of reserves that, for exampie, insurance companies or a government should maintain to avoid excessive losses that might exceed their capacity to spend. The risk model defines it as the average loss that could occur for a given return period.

Figure 6 shows the PML curve obtained for the complete portfolio of private buildings of Manizales. The red dot in this curve indicates that, in the case of the insurance of Manizales, the used return period is 1500 years ${ }^{9}$, that would mean a PML of $13,6 \%$ of the portfolio. Table 3 shows the probabilistic results for each portfolio of the city with the 3\% of deductible which is the current standard deductible for earthquake in the insurance market. Nevertheless, Table 4 shows the results for different deductibles $(0 \%, 1,5 \%$ and $3 \%$ ) to illustrate their effects on the values of the pure premium and the PML. Figure 7 shows a detailed visualization of the pure premium of each building using the SisMan+ Risk system (INGENIAR and ITEC, 2005). The aim of SisMan+ Risk tool is to facilitate the risk visualization (i.e. pure risk premium, potential losses scenarios), thus better understanding risk and proposing actions to intervene in high-risk areas.

\footnotetext{
${ }^{9}$ For insurance purposes, the return period defined in Colombia is 1500 years.
} 


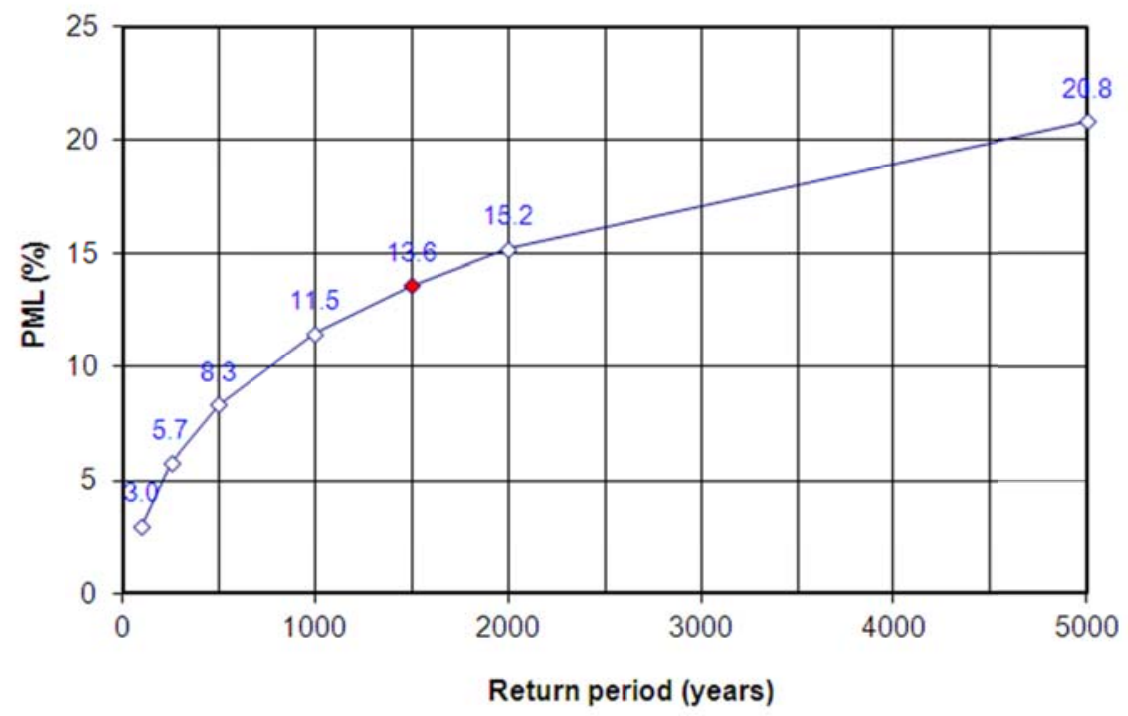

Figure 6. PML curve of the private buildings of Manizales

Table 3. Results obtained for non-taxpayers, taxpayers, and the total portfolio of buildings with a deductible of $3 \%$

\begin{tabular}{|c|c|c|c|c|c|c|c|}
\hline \multicolumn{8}{|c|}{ DEDUCTIBLE 3\% } \\
\hline \multirow{2}{*}{\multicolumn{2}{|c|}{ ASPECT }} & \multicolumn{6}{|c|}{ PRIVATE BUILDINGS } \\
\hline & & \multicolumn{2}{|c|}{ EXEMPT } & \multicolumn{2}{|c|}{ NON-EXEMPT } & \multicolumn{2}{|c|}{ TOTAL } \\
\hline \multicolumn{2}{|c|}{ Number of buildings } & \multicolumn{2}{|c|}{15.342} & \multicolumn{2}{|c|}{70.474} & \multicolumn{2}{|c|}{85.816} \\
\hline \multicolumn{2}{|c|}{$\begin{array}{l}\text { Insured value } \\
\text { (Million Col\$) }\end{array}$} & \multicolumn{2}{|c|}{78.590} & \multicolumn{2}{|c|}{3.036 .460} & \multicolumn{2}{|c|}{3.115 .050} \\
\hline \multirow{2}{*}{\multicolumn{2}{|c|}{ Pure Premium }} & $\begin{array}{c}\text { Million } \\
\text { Col\$ }\end{array}$ & $\begin{array}{c}0 / 00 \\
\text { cadastral }\end{array}$ & Million Col\$ & $\begin{array}{c}0 / 00 \\
\text { cadastral }\end{array}$ & Million Col\$ & $\begin{array}{c}0 / 00 \\
\text { cadastral }\end{array}$ \\
\hline & & 56 & 0,741 & 5.736 & 1,963 & 5.792 & 1,982 \\
\hline \multirow{5}{*}{ PML } & Return periods & $\begin{array}{c}\text { Million } \\
\text { Col\$ }\end{array}$ & $\begin{array}{c}\% \% \\
\text { cadastral }\end{array}$ & Million Col\$ & $\begin{array}{c}\% \\
\text { cadastral } \\
\end{array}$ & Million Col\$ & $\begin{array}{c}\% \% \\
\text { cadastral }\end{array}$ \\
\hline & 100 years & $\$ 1,394$ & $1.42 \%$ & $\$ 115,079.72$ & $3.03 \%$ & $\$ 116,445.89$ & $2.99 \%$ \\
\hline & 500 years & $\$ 5,388$ & $5.48 \%$ & $\$ 320,464.01$ & $8.43 \%$ & $\$ 325,644.18$ & $8.35 \%$ \\
\hline & 1000 years & $\$ 7,421$ & $7.55 \%$ & $\$ 441,982.26$ & $11.59 \%$ & $\$ 449,192.38$ & $11.49 \%$ \\
\hline & 1500 years & $\$ 8,936$ & $9.09 \%$ & $\$ 523,991.72$ & $13.72 \%$ & $\$ 532,788.96$ & $13.60 \%$ \\
\hline \multicolumn{2}{|c|}{ Expected Loss (\%) } & $\$ 26,747$ & $26.51 \%$ & $\$ 1,160,860.83$ & $29.72 \%$ & $\$ 1,187,607.83$ & $29.64 \%$ \\
\hline
\end{tabular}

Table 4. Effects of deductible in the premium value and PML for the total portfolio

\begin{tabular}{|c|c|c|c|c|c|}
\hline $\begin{array}{c}\text { Deductible } \\
{[\%]}\end{array}$ & $\begin{array}{c}\text { Deductible } \\
{[\text { Million Col] }}\end{array}$ & $\begin{array}{c}\text { Pure premium } \\
{[\% \text { ] }]}\end{array}$ & $\begin{array}{c}\text { Pure premium } \\
{[\text { Million Col] }}\end{array}$ & $\begin{array}{c}\text { PML 1500 } \\
{[\%]}\end{array}$ & $\begin{array}{c}\text { PML 1500 } \\
{[\text { Million Col] }}\end{array}$ \\
\hline $\mathbf{0}$ & 0 & 3.210 & $\$ 9,747$ & $16.00 \%$ & $\$ 498,441.35$ \\
\hline $\mathbf{1 . 5}$ & $\$ 46,725.75$ & 2.388 & $\$ 7,116$ & $14.75 \%$ & $\$ 459,413.84$ \\
\hline $\mathbf{3}$ & $\$ 93,451.49$ & 1.982 & $\$ 5,792$ & $13.60 \%$ & $\$ 532,788.96$ \\
\hline
\end{tabular}




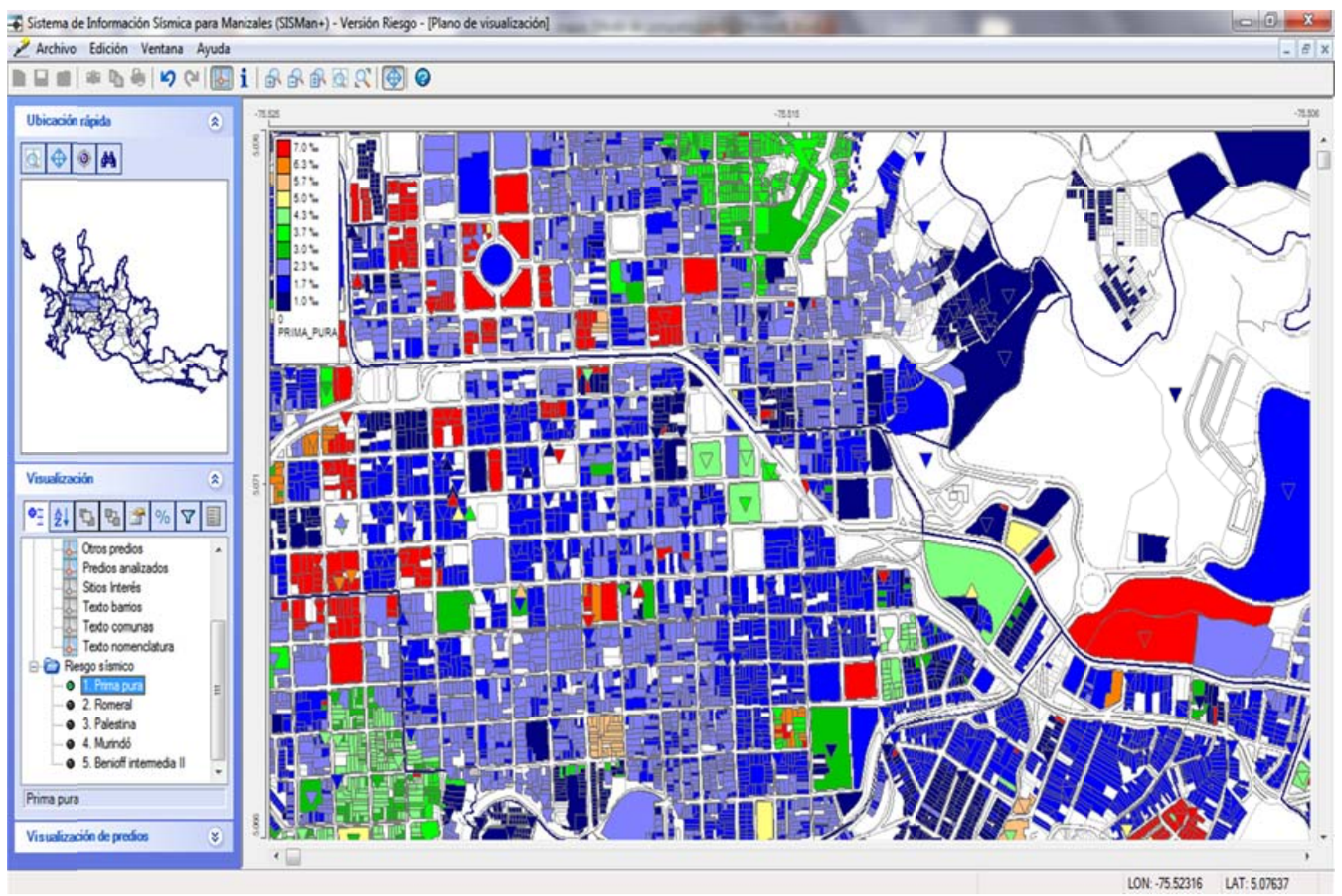

Figure 7.Screenshot of the SisMan+Risk showing the results of the pure premium for the buildings of Manizales

\section{IMPLEMENTATION OF THE COLLECTIVE INSURANCE INITIATIVE}

Extreme disasters are characterized by the occurrence of low frequency/high severity phenomena and by the difficulty of predicting the moment and place of their occurrence. The level of severity of the consequences and losses generated by large events can cause insolvency problems and economic insecurity in a city or even at national level. Thus, a strategy to face those probable losses is the design of alternative structures adequately combining financial instruments to cover different levels of losses. The layers of the financing structure must be established according to the costs of the available instruments and the capacity of the government to acquire them. From the governmental side, these kind of structures allow to face the consequences of extreme events without compromising the financial and fiscal stability and minimizing social losses (Pollner, 2001, Marulanda et al., 2008, Cardona, 2009, Cummins and Mahul, 2009).

A financing structure of risk retention and risk transfer, schematically shown in Figure 8, is a bidimensional representation of the loss, frequently used in the insurance modeling. In its simplest form, the structure basically consists of three main parameters that must be taken into account when it is designed: the deductible or retention limit -this is the priority or attachment point of risk transfer layer-, the maximum limit of responsibility -or excess of loss limit of the risk transfer layer- and the total value of the exposure. In turn, theses loss layers can be composed of other sub-layers where each one represents a financial instrument, such as a reserve fund, a contingent credit, insurance/reinsurance, a cat bond, taxes or other credits, among others provided by the multilateral financing organizations such as the World Bank and the Inter-American Development Bank. The size of the layers 
and the adopted combination depend on the costs of the financial instruments which cover each level of losses. Additionally, it is not cost-effective to use a unique instrument; lack of liquidity can impede to cover a complete portfolio. For example, in the case of insurance, premiums could be prohibitively high if one wants to cover the lower layer of losses, that is, the more frequent losses or the upper layers (Banks, 2004, Marulanda et al., 2008, Cardona, 2009 and Marulanda 2013). In the case of the collective insurance initiative of Manizales which covers with cross-subsidies the low-income homeowners (nontaxpayers), Figure 9 shows alternative values of coverage, in millions Colombian pesos (MDP).

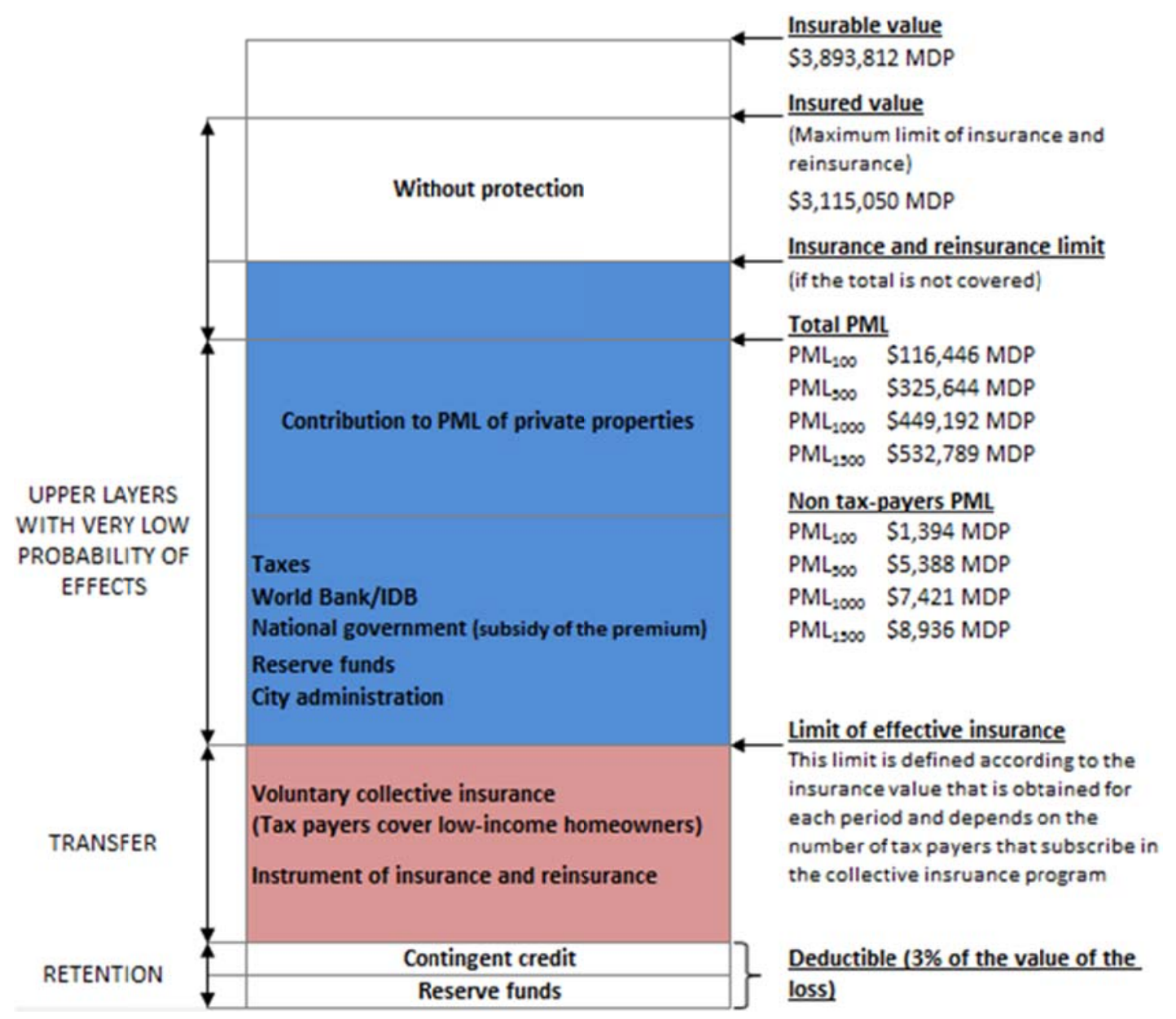

Figure 8.Financing structure of risk retention and risk transfer in Manizales to cover private properties

Figure 9 illustrates the hypothetical economic costs of each strategy that can be explored by a government, considering risk retention (own capital) and risk transfer, (insurancereinsurance and the capital market). In general, this scheme can be considered as feasible or appropriate in all cases. The risk appetite of the government would define what limits $(\mathrm{k} 1, \mathrm{k} 2, \mathrm{k} 3)$ of retention and transfer instruments are optimal according to the cost of the origin of resources required for various levels of coverage (ERN-AL, 2011). Considering the alternatives indicated, it can be deduced from the figure that it is not optimal to finance the entire loss from a single financing source; there are other financing alternatives that can cost less at certain intervals. For that reason, in theory, it is necessary to construct a function of total costs that represents the weighted sum of financing sources and that, using optimization algorithms, helps to find the optimum cost (in this case the minimum) based 
on that function. Although an algorithm that helps finding the optimal cost can be developed, in practice this would be subjected to the insurance and reinsurance market conditions, which are also driven by capacity vs. demand.

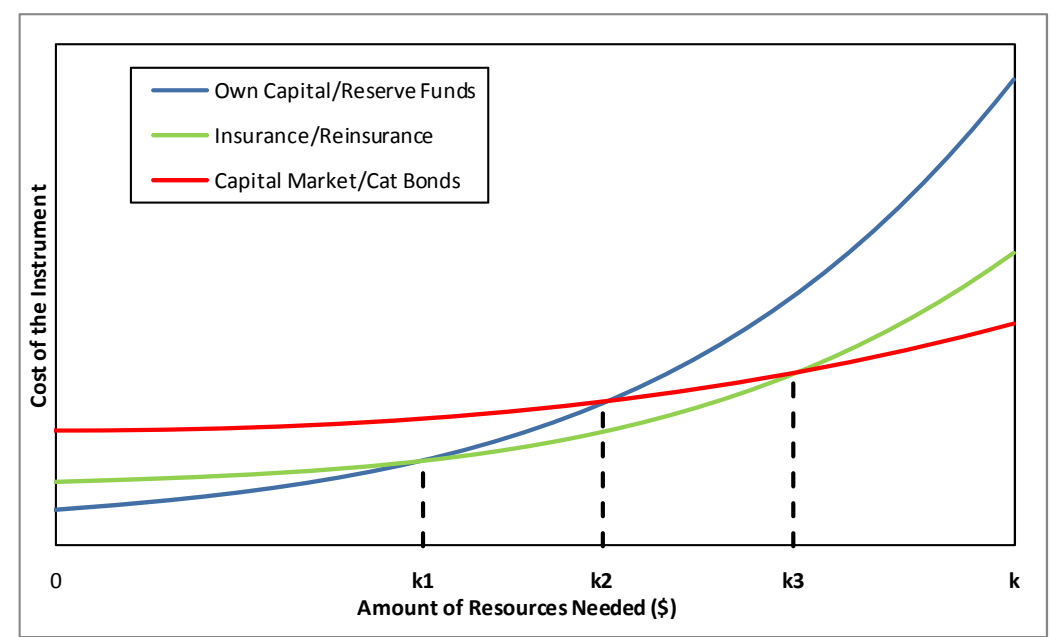

Figure 9.Scheme of the general financial cost according to the losses that must be covered

Overall, the designed structure of risk retention and transfer takes into consideration the interaction between the different beneficiaries: householders with intermediate-high economic capacity to pay their insurance, low-income homeowners and the municipal government as the co-responsible of losses. The alternative chosen was oriented towards the economic capacities, the social conditions, the will of the government and the attractive incentives for the majority of the homeowners. Different structures of risk retention and risk transfer were proposed according to the results of different portfolios obtained with the risk modeling. It was also considered the analysis of alternatives related to the retention levels and maximum limits of coverage based on the budget availability in the city. Once a set of structures were exposed, the Mayor, the Financial and Legal Secretariats of the local administration and the Disaster Risk Management Directorate of Manizales chose the structure most affordable for all involved parties.

As shown in the Figure 8, the deductible chosen was 3\% because the pure premium for private buildings was more affordable than the one with a lower deductible. A lower pure premium was not convenient because it would mean a lower coverage with greater values of retention. This priority or deductible must be assumed by the insured (the property-tax payers), but the government covers these first layer of losses of the low-income homeowners through a reserve fund for disaster risk management. This fund is composed by a percentage assigned from the local budget and, above a given excess of loss threshold, by a national contingent credit (World Bank CAT DDO of US $\$ 250$ millions) agreed by the national government with the World Bank, with which the national government supports financially the local government. When the attachment point is reached the transfer layer is covered by the collective insurance instrument provided by La Previsora insurance company up to an excess of loss that was defined between the insurance company and the city administration. Thus, to cover up the total cadastral value of all properties the upper layers are estimated to be supported with another percentage of the national contingent credit, or with the support of other resources of the national government. 
Now then, one of the proposals of the design of a collective voluntary insurance was to cover, in some way, the losses of the poor people of the city. So, when analyzing the three portfolios, it was possible to reveal that the cadastral value of the low-income properties was not significant when compared with the rest of the value of the private buildings of the city. This gave the possibility to consider a subsidy for the socio-economic layers 1 and 2, assuming their pure premium the taxpayers that decided to subscribe the insurance program (Marulanda, 2009; Marulanda 2013).

Because this is a voluntary insurance program, the percentage of taxpayers that pay the premium could vary significantly. Figure 10 shows the cost of the blanket pure premium of the non-exempt homeowners according to the level of insurance participation and considering the cross subsidy (covering the low-income homeowners or property tax exempts). It can be seen that, for a participation of $10 \%$, the premium without the portfolio of low-income homeowners is $2.1 \%$ while, when it is included, the value is $2.3 \%$. When the participation increases to $20 \%$, the premium without subsidy is $2.0 \%$ and, when including the subsidy, it is $2.1 \%$. These values are affordable for both, the city administration and the participant taxpayers, given that, although the pure premium increases when including the subsidy, as expected, this increase is not significant. This demonstrates that the proposed cross-subsidy mechanism for covering the expected losses of low-income people is viable (Marulanda, 2009; 2013).

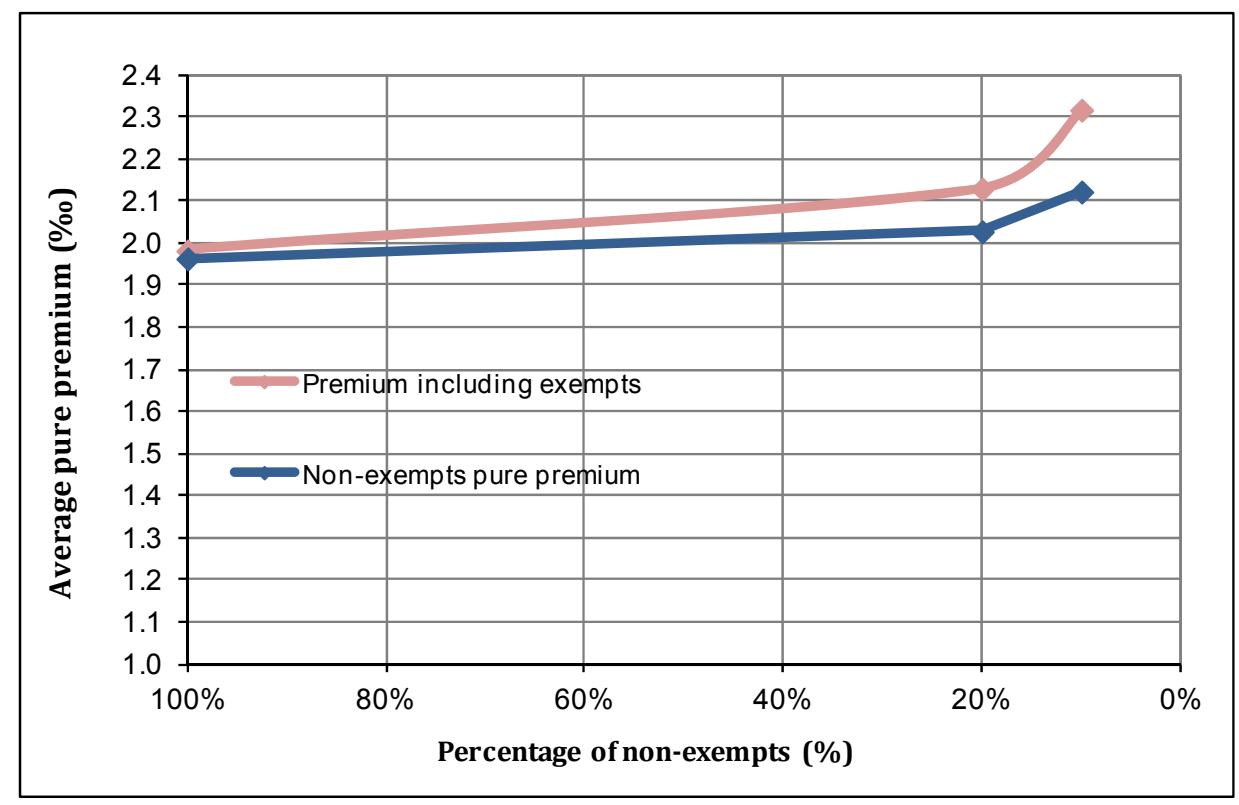

Figure 10. Blanket pure premium for non-exempt properties portfolio for different levels of insured value with respect to the total portfolio.

In summary, Figure 11 shows schematically the basic collective insurance structure of Manizales. The first layer of this structure (deductible or priority) is the responsibility of each owner with the exception of socio-economic layers 1 and 2 for which the municipal government assumes this first layer of the losses. The second layer of the structure is the insurance instrument itself, where the middle and high income homeowners which participate in the program are contributing to cover the losses of the lowest socio-economic 
layers. When losses exceed the upper limit of the policy, other alternatives are considered, such as the financial support of the national government or donors or NGOs.

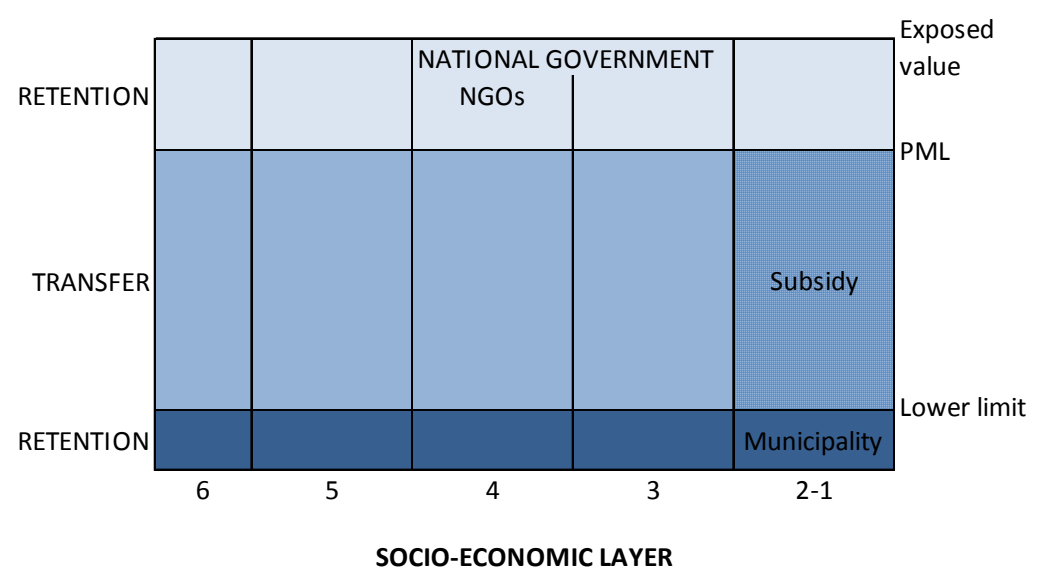

Figure 11. Basic financing structure of risk retention and transfer developed for the city of Manizales to cover low-income homeowners

\section{CONCLUSIONS}

Within the framework of the collective insurance program of Manizales, a blanket premium of $2.5 \%{ }^{10}$ of the cadastral value of each building has been estimated and agreed with La Previsora insurance company. The deductible is 3\% of loss value in case of earthquake and at least three current minimum legal monthly salaries. In the cases of other natural hazards or events like strike, riot, civil or popular commotion, bad intentioned acts to third parties or terrorism, the deductible was agreed to be $10 \%$ of the loss of the affected building and at least two minimum legal monthly salaries. The insurance company La Previsora issued a matrix policy for which the Manizales municipality is the taker on behalf of the citizens. This policy is filed in the Mayor's office, in a notary's office and in a branch of the insurance company of Manizales, and is available to the users for revision. Given that the average participation has been of the order of $12 \%$ of the taxpayers of the $\mathrm{city}^{11}$, an agreement between the public administration and the insurance company was settled. At present, with this percentage of participation of taxpayers, the total low-income homeowners of Manizales are covered with the collective insurance.

This innovative financial protection instrument implemented in Manizales, Colombia, that has been improved with careful studies of scientific-technical and actuarial character constitutes, without any doubt, a successful experience and it is a good practice promoted by the local government and the national insurance market.

This initiative is mainly a social action of the local government which, when it is feasible, is also supported by the national government. The cost effectiveness is clear from sustainability, prevention, socio-economic well-being, financial protection and reduction of the macroeconomic contingent liabilities points of view. It has been based on technical studies made with robust engineering risk models, but the most important elements of this

\footnotetext{
${ }^{10}$ Within the technical premium, the operational costs, acquisition and utility are included, among others.

${ }^{11}$ The owners with mortgage are not participating in the program because they already have compulsory property insurance.
} 
initiative are the political will, governance, citizen solidarity, and risk perception of the society and the government leaders and officials. This mechanism of risk transfer can be replicated in other disaster-prone developing countries, if appropriate risk studies are made for its implementation. This initiative has been acknowledged as one of the best disaster risk management practices in the Latin America and the Caribbean region by the United Nations International Strategy of Disaster Risk Reduction (Regional platform for disaster risk reduction in the Americas, Chile, November 2012)

Finally, it is important to mention that the results of a probabilistic risk model are useful for different other applications in a city or a country. For example, the risk results obtained for Manizales were also used to calculate the Urban Seismic Risk Index, USRi, of the city's districts by means of a holistic approach to seismic risk evaluation (Carreño et al., 2007, Marulanda et al., 2009, Barbat et al. 2011).

\section{ACKNOWLEDGEMENTS}

This work has been partially sponsored by DESURBS-FP7-2011-261652. The authors are also grateful for the support of the World Bank, the IDRC ECOPOLIS Graduate Research Program of Canada and of the Ministry of Education and Science of Spain, project "Enfoque integral y probabilista para la evaluación del riesgo sísmico en España"CoPASRE (CGL2011-29063).

\section{REFERENCES}

AIS-300 C (1996) Estudio general de amenaza sísmica de Colombia. In (ed.), Vol. pp. Asociación Colombiana de Ingeniería Sísmica, Bogotá, Colombia.

Andersen TJ (2002) Innovative Financial Instruments for Natural Disaster Risk Management. In Technical paper. (ed.), Vol. pp. Inter-American Development Bank,

Banks E (2004) In Alternative Risk Transfer: Integrated Risk Management Through Insurance, Reinsurance, and the Capital Markets. Vol. pp. John Wiley \& Sons,

Barbat AH, Carreño ML, Pujades LG, Lantada N, Cardona OD, and Marulanda MC (2010) Seismic vulnerability and risk evaluation methods for urban areas. A review with application to a pilot area. Structure and Infrastructure Engineering 6, 499-.

Barbat AH, Pujades LG, N. L, and R. M (2006) Performance of buildings under earthquakes in Barcelona, Spain. Computer-Aided Civil and Infrastructure Engineering 21, 573-93.

Birkmann J, Cardona OD, Carreño ML, Barbat AH, Pelling M, Schneiderbauer S et al. (2013) Framing vulnerability, risk and societal responses: the MOVE framework. Natural Hazards 67, 193-211.

Cardona OD (2009) In La gestión financiera del riesgo de desastres: Instrumentos financieros de retención y transferencia para la comunidad Andina. Vol. pp. Lima.

Cardona OD, Lavell AM, Mansilla E, and Moreno AM (2005a) Avances en las estrategias de desarrollo institucional y sostenibilidad financiera de la gestión del riesgo de desastres en América Latina y el Caribe. In diálogo Regional de Poítica sobre Prevención de Desastres. (ed.), Vol. pp. Banco Interamericano de Desarrollo, BID, Washington.

Cardona OD and Marulanda MC (2010) Mecanismos Financieros, Seguro y Reaseguro contra Desastres Naturales en América Latina y el Caribe: Experiencias Recientes. In (ed.), Vol. pp. 
Secretaría Permanente del Sistema Económico Latinoamericano y del Caribe, SELA, Caracas.

Cardona OD, Ordaz MG, Marulanda MC, and Barbat AH (2008a) Estimation of Probabilistic Seismic Losses and the Public Economic Resilience-An Approach for a Macroeconomic Impact Evaluation. Journal of Earthquake Engineering 12, 60-70.

Cardona OD, Ordaz MG, Marulanda MC, and Barbat AH (2008b) Fiscal Impact of future earthquakes and country's economic resilience evaluation using the disaster deficit index. In 14th World Conference on Earthquake Engineering. (ed.), Vol. pp. Beijing, China.

Cardona OD, Ordaz MG, Moreno AM, and Yamin LE (2004) Análisis de riesgo de desastres extremos en Colombia con fines de valoración de la exposición fiscal. In Informe del estudio sobre definición de la responsabilidad del Estado, su exposición ante desastres naturales y diseño de mecanismos para la cobertura de los riesgos residuales del Estado. (ed.), Vol. pp. ACCI, DNP, Banco Mundial,

Cardona OD, Ordaz MG, Moreno AM, and Yamin LE (2005b) Obligaciones contingentes del Estado por desasatre, requerimiento de recursos y posibilidades de asignación. In Informe del estudio sobre definición de la responsabilidad del Estado, su exposición ante desastres naturales y diseño de mecanismos para la cobertura de los riesgos residuales del Estado. (ed.), Vol. pp. ACCI-DNP, Banco Mundial,

Cardona OD, Ordaz MG, Reinoso E, Yamín LE, and Barbat AH (2010) Comprehensive Approach for Probabilistic Risk Assessment (CAPRA): International Initiative for Disaster Risk Management Effectiveness. In 14th European Conference on Earthquake Engineering. (ed.), Vol. pp. Ohrid, Macedonia.

Cardona OD, Ordaz MG, Yamin LE, Arámbula S, Marulanda MC, and Barbat AH (2008c) Probabilistic seismic risk assessment for comprehensive risk management: modeling for innovative risk transfer and loss financing mechanisms. In 14th World Conference on Earthquake Engineering. (ed.), Vol. pp. Beijing, China.

Cardona OD, Ordaz MG, Yamin LE, Marulanda MC, and Barbat AH (2008d) Earthquake Loss Assessment for Integrated Disaster Risk Management. Journal of Earthquake Engineering $12,48-59$.

Carreño ML, Cardona OD, and Barbat AH (2007) Urban Seismic Risk Evaluation: A Holistic Approach. Natural Hazards 40, 137-72.

CEDERI (2002) Microzonificación Sísmica de la Ciudad de Manizales. In (ed.), Vol. pp. Centro de Investigación en Materiales y Obras Civiles, Centro de Estudios sobre Desastres y Riesgos, Departamento de Ingeniería Civil y Ambiental, Universidad de los Andes, Bogotá, Colombia.

Consorseguros (2008) La cobertura aseguradora de las catástrofes naturales. Diversidad de sistemas. In Seguros CdCd (ed.), (ed.), Vol. pp. Madrid.

Cummins JD and Mahul O (2009) In Catastrophe Risk Financing in Developing Countries: Principles for Public Intervention. Vol. pp. World Bank,

Egozcue JJ, Barbat AH, Canas JA, Miquel J, and Banda E (1991) A method to estimate occurrence probabilities in low seismic activity regions. Earthquake Engineering and Structural Dynamics 20, 43-60.

ERN-AL (2011) Probabilistic modelling of disaster risk at global level: Development of a methodology and implementation of case studies. Phase 1A: Colombia, Mexico, Nepal. In Backgroud paper prepared for the 2011 Global Assessment Report on Disaster Risk Reduction. Prepared by the Consortium Evaluación de Riesgos Naturales - América Latina. (ed.), Vol. pp. UNISDR, Geneva, Switzerland.

ERN (1999) Sistema para la evaluación de pérdidas por terremoto en edificaciones con fines de seguro (Version 2.5.1). Bogotá. 
Freeman PK, Keen M, and Mani M (2003) In Dealing with increased risk of natural disasters: challenges and options. Vol. pp. International Monetary Fund, Fiscal Affairs Dept.,

Gallego M (2000) Estimación del riesgo sísmico en la república de colombia[Thesis]. Type, Universidad Nacional Autónoma de México, Ciudad de México.

Grossi P and Kunreuther H (2005) In Catastrophe Modeling: A New Approach to Managing Risk. Vol. pp. Springer US, Boston.

Gurenko E, Lester R, Mahul O, and Gonulal S (2006) In Earthquake Insurance in Turkey. History of the Turkish Catastrophe Insurance Pool. Vol. pp. The World Bank, Washington, D.C.

INGENIAR and ITEC (2005) Sistema de Información Sísmica de Manizales. Versión Riesgo.

ITEC (2004) Sistema de Información Sísmica de Manizales - SISMan.

Marulanda MC (2009) Design and implementation of a collective disaster risk transfer instrument for the insurance coverage of low-income homeowners by cross-subsidies in Manizales, Colombia : technical report. In ECOPOLIS Graduate Research and Design Competition (Global). (ed.), Vol. pp. Universidad Nacional de Colombia, Manizales, CO,

Marulanda MC (2013) Modelación probabilista de pérdidas económicas por sismo para la estimación de la vulnerabilidad fiscal del Estado y la gestión financiera del riesgo soberano[Thesis]. Type, Universidad Politécnica de Cataluña (UPC), Barcelona, Spain.

Marulanda MC, Cardona OD, and Barbat AH (2010) Revealing the socioeconomic impact of small disasters in Colombia using the DesInventar database. Disasters 34, 552-70.

Marulanda MC, Cardona OD, and Barbat AH (2009) Robustness of the holistic seismic risk evaluation in urban centers using the USRi. Natural Hazards 49, 501-16.

Marulanda MC, Cardona OD, Ordaz MG, and Barbat AH (2008) In La gestión financiera del riesgo desde la perspectiva de los desastres: Evaluación de la exposición fiscal del estado y alternativas de instrumentos financieros de retención y transferencia del riesgo. Vol. pp. Centro Internacional de Métodos Numéricos en Ingeniería, Barcelona, Spain.

Marulanda MC, Carreño ML, Cardona OD, Ordaz MG, and Barbat AH (2013) Probabilistic earthquake risk assessment using CAPRA: application to the city of Barcelona, Spain. Natural Hazards 1-26.

Mechler R, Hochrainer S, Linnerooth-Bayer J, and Pflug G (2006) Public sector financial vulnerability to disasters: The IIASA CATSIM Model. In Measuring Vulnerability to Hazards of Natural Origin: Towards Disaster Resilient Societies. Birkmann J (ed.), Vol. pp. 380-98. United Nations University Press, Tokyo.

Miranda E (1999) Approximate Seismic Lateral Deformation Demands in Multistory Buildings. Journal of Structural Engineering 125, 417-25.

Ordaz MG (2000) Metodología para la Evaluación del Riesgo Sísmico Enfocada a la Gerencia de Seguros por Terremoto. In (ed.), Vol. pp. Universidad Nacional Autónoma de México, México D.F.

Ordaz MG, Miranda E, Reinoso E, and Pérez-Rocha LE (1998) Seismic Loss Estimation Model for México City. In Universidad Nacional Autónoma de México. (ed.), Vol. pp. México DF., México.

Pollner JD (2001) Managing catastrophic disaster risks using alternative risk financing and pooled insurance structures. In Technical paper ; no. WTP 495 (ed.), Vol. pp. World Bank,

Vargas JE (2002) In Politicas Publicas para la Reduccion de la Vulnerabilidad Frente a los Desastres Naturales y Socio-naturales. Vol. pp. Naciones Unidas, CEPAL, División de Medio Ambiente y Asentamientos Humanos,

Woo G (2011) In Calculating catastrophe. Vol. pp. Imperial College Press ; Distributed by World scientific Publishing Co., London; Singapore. 
Woo G (1999) In The Mathematics of Natural Catastrophes. Vol. pp. Imperial College Press, 